\title{
Fuel consumption analysis in dynamic states of the engine with use of artificial neural network
}

\begin{abstract}
The paper presents the construction of fuel consumption dynamic characteristic determined with use of artificial neural network (ANN). The characteristic is based on the data obtained during measurements carried out on the engine dynamometer. The momentary fuel consumption as a non-linear function of two variable parameters, engine speed and torque, has been presented. Article discusses the way of determining such a characteristic which can be used for both SI and CI engines for entire range of engine speed and load. Described characteristic enables analysis of engine properties in dynamic states and allows computing mileage fuel consumption of the car with a given engine in combination with the specific transmission in any virtual driving cycle. An important advantage of the ANN method in case of general fuel consumption characteristic in dynamic operating states is that standard measurement equipment can be used and the solution to a complex problem is reduced to programming issues.
\end{abstract}

Key words: dynamic characteristics, fuel consumption, artificial neural networks

\section{Analiza zużycia paliwa w dynamicznych stanach pracy silnika z zastosowaniem sztucznej sieci neuronowej}

\begin{abstract}
$W$ artykule zaprezentowano charakterystyke dynamiczna zużycia paliwa, wyznaczona z wykorzystaniem sztucznej sieci neuronowej (SSN),opierając się na danych z pomiarów przeprowadzanych na hamowni silnikowej. Przedstawiono chwilowe zużycie paliwa jako nieliniowa funkcję dwóch zmiennych parametrów pracy silnika: prędkości obrotowej i momentu obrotowego, a następnie omówiono sposób sporządzania charakterystyki, która może być zastosowana w odniesieniu do silników ZI i ZS dla catego zakresu prędkości obrotowej i obciązenia. Opisana charakterystyka umożliwia analizę właściwości silników w stanach dynamicznych oraz wstępne obliczanie przebiegowego zużycia paliwa samochodu $z$ danym silnikiem $w$ konfiguracji z określonym układem przeniesienia napędu $w$ dowolnym wirtualnym cyklu jezdnym. Niewatpliwa zaleta wykorzystania metody SSN do sporządzania ogólnej charakterystyki zużycia paliwa $w$ dynamicznych stanach pracy jest możliwość wykorzystania standardowej aparatury pomiarowej do przeprowadzenia badań, a rozwiąanie złożonego problemu zostaje sprowadzone do zakresu programowania.
\end{abstract}

Słowa kluczowe: charakterystyki dynamiczne, zużcie paliwa, sztuczne sieci neuronowe

\section{Introduction}

Operating parameters of internal combustion engines change continuously under real traffic conditions. It pertains particularly to driving in a city traffic, where vehicles move at variable speed by a significant percent of time. In the measurements done by the author in a city of Krakow, it was $14 \%-68 \%$ of the total travel time (depending on the time of day and the route) while the Directive [6], according to which the homologation tests are performed, defines it on $31.3 \%$. The use of an universal characteristic for calculating the momentary fuel consumption under these conditions leads to inaccurate results. Such action does not take into account series of phenomena occurring in the engine in dynamic operating states, e.g. changes in kinetic energy of parts in motion or changes in fluid flow resistance in the cooling and lubrication systems, intake and exhaust manifolds or delay in engine response to the control signal.

The homologation tests carried out on chassis dynamometers allow to understand internal combustion engines properties in dynamic states. They characterize not only the engine, but also the transmission which significantly influences fuel consumption. Additionally, these tests apply only to a specific driving cycle $[6,7]$. It is impossible to obtain the value of the fuel consumption for a different

\section{Wstęp}

Parametry robocze silnika spalinowego samochodu, pracującego w rzeczywistych warunkach drogowych, stale się zmieniają. Dotyczy to zwłaszcza jazdy w ruchu miejskim, gdzie pojazdy poruszają się ze zmienną prędkością przez znaczny procent czasu. W pomiarach przeprowadzonych przez autora niniejszego opracowania wynosi on, w warunkach miasta Krakowa, w zależności od pory dnia i trasy, od $14 \%$ do $68 \%$ całkowitego czasu przejazdu (Dyrektywa [6], zgodnie z którą przeprowadzane są testy homologacyjne określa go na 31,3\%). Stosowanie charakterystyki uniwersalnej do obliczania chwilowego zużycia paliwa w takich warunkach nie pozwala na uzyskanie dokładnych danych. Wynika to z tego, że nie uwzględnia się w ten sposób wielu zjawisk zachodzących w silniku w dynamicznych stanach pracy, m.in. zmiany energii kinetycznej elementów znajdujących się w ruchu obrotowym, zmieniających się wraz z prędkością obrotową oporów przepływu płynów w układach chłodzenia, smarowania, dolotowym i wylotowym, czy też opóźnienia reakcji układu na sygnał sterowania.

Testy na hamowniach podwoziowych wykonywane w celu homologacji danego typu pojazdu umożliwiają poznanie właściwości silników spalinowych $\mathrm{w}$ stanach dynamicznych, ale na wartość przebiegowego zużycia paliwa 
cycle without performing a test on a chassis dynamometer. This is a drawback of this method which is basically used to compare the functional characteristics of different cars, as tests are always performed in the same conditions. There is a possibility to determine the approximated dynamic vehicle characteristics but they are created on the basis of research performed on a chassis dynamometer and refer to a given engine and vehicle type [16]. Similarly, in case of engine dynamometer tests performed with use of an electronically controlled brakes that enable implementing repeatable test cycles [15]. Determining, e.g. fuel consumption in a particular cycle requires programming the brake and carrying out the test for every new case. Described methods enable the study of engines properties in dynamic states but they do not solve the problem of drawing general characteristic as it occurs in static operating states (e.g. universal characteristic).

The problem of testing combustion engines in dynamic states is that the non-linear processes of variable parameters are analyzed. This creates significant difficulties in testing engine properties in general - that is why studies are commonly carried out only for specific cases, for example measuring the opacity at free-acceleration (CI engines) [5]. However, the exploitation properties strongly depend on the occurrence of dynamic states, therefore there is a strong need for their more detailed analysis. Because of the necessity to reduce harmful exhaust emission and carbon dioxide, it is desirable to develop the method of determining characteristic of momentary fuel consumption in such states without the need for costly implementation of driving cycles on chassis dynamometer or tests on engine dynamometer for every considered course of engine speed and torque.

This paper presents the concept of building the fuel consumption dynamic characteristic - non-linear function of two variable working parameters: engine speed and torque, analyzed in a certain period of time. The term characteristic in its origin refers to the graphical relation between certain working parameters, but in this case the momentary fuel consumption is a function of six variables (as a result of considering parameters in a time window), therefore this relationship can be shown only as a function (11).

ANN, which was used to analyze measurement data, is a commonly used method in the field of internal combustion engines for the reduction of exhaust emission. This is due to the fact that exhaust emission is highly dependent on dynamic states and is influenced by many factors. Other ANN applications refer to calculating specific fuel consumption or momentary engine torque as a function of other working parameters. There exist various configurations of input and output parameters. The final choice is determined by the goal to be achieved and the factors that researchers consider important and which can be measured during tests. Selected applications of ANN in the field of internal combustion engines are:

- determining specific fuel consumption, exhaust gas temperature and air/fuel ratio on the basis of engine power, effective pressure and engine temperature [4],

- identifying the SI engine power characteristic on the basis istotnie wpływa w tym przypadku układ przeniesienia napędu. Ponadto testy te odnoszą się tylko do konkretnego cyklu jezdnego $[6,7]$. Nie jest możliwe uzyskanie wartości zużycia paliwa dla innego cyklu bez wykonania testu na stanowisku pomiarowym. Jest to wadą tej metody, która służy zasadniczo do porównania cech użytkowych różnych samochodów, gdyż badania wykonywane są zawsze w takich samych warunkach. Istnieje możliwość wyznaczania aproksymowanych charakterystyk dynamicznych, jednak powstają one na podstawie testów na hamowniach podwoziowych i odnoszą się do danego typu silnika i pojazdu [16]. Podobnie jest przy badaniach stanowiskowych na hamowaniach silnikowych z zastosowaniem elektronicznie sterowanych hamulców umożliwiających realizację powtarzalnych cykli badawczych [15]. Wyznaczenie np. zużycia paliwa w określonym cyklu wymaga zaprogramowania hamulca i przeprowadzenia testu dla każdego nowo rozpatrywanego przypadku. Opisane metody umożliwiają badanie właściwości dynamicznych silników, nie rozwiązuje to jednak problemu sporządzenia ogólnej charakterystyki, co występuje w sytuacji statycznych stanów pracy (charakterystyka uniwersalna).

Problem badań silników spalinowych w stanach dynamicznych wynika z faktu, że analizie podlegają procesy nieliniowe zmiennych parametrów pracy. Stwarza to znaczne trudności w ogólnym badaniu silników, dlatego powszechnie przeprowadzane są testy tylko dla szczególnych sytuacji, np. pomiaru zadymienia spalin w trakcie swobodnego rozpędzania (silniki ZS) [5]. Jednak świadomość, że właściwości użytkowe silników spalinowych silnie zależą od stanów dynamicznych, zmusza do ich dokładniejszej analizy. Z uwagi na konieczność ograniczania emisji szkodliwych składników spalin i dwutlenku węgla, pożądane jest opracowanie metody umożliwiającej wyznaczenie ogólnej charakterystyki chwilowego zużycia paliwa w takich stanach bez realizacji kosztownych testów na hamowniach dla każdego rozpatrywanego przebiegu prędkości obrotowej i momentu obrotowego.

W artykule przedstawiono koncepcję budowy charakterystyki dynamicznej zużycia paliwa - nieliniowej funkcji dwóch zmiennych parametrów pracy: prędkości obrotowej i momentu obrotowego, analizowanych w oknie czasowym. Termin charakterystyka w podstawowym znaczeniu odnosi się do graficznej zależności między określonymi parametrami pracy, jednak w tym przypadku chwilowe zużycie paliwa jest funkcją sześciu zmiennych (w wyniku uwzględnienia parametrów w pewnym przedziale czasu), przez co możliwe jest jej przedstawienie jedynie w postaci wzoru (11).

Do analizy danych wykorzystano SSN, których zastosowania w dziedzinie silników spalinowych skupiają się w dużej mierze na ograniczaniu emisji szkodliwych składników spalin. Wynika to $\mathrm{z}$ tego, że jest ona bardzo zależna od dynamicznych stanów pracy, a na jej wielkość wpływa wiele czynników składowych. SSN stosuje się także m.in. do obliczania jednostkowego zużycia paliwa lub chwilowego momentu obrotowego jako funkcji innych parametrów pracy. Różnorodność konfiguracji zmiennych wejściowych i wyjściowych jest niezwykle duża. Ostateczny ich wybór 
of engine speed and the vacuum in the intake manifold measured under real traffic conditions [12],

- analysis of particulate emission in CI engines [2],

- determining torque and specific fuel consumption on the basis of the ignition advance angle, throttle opening angle and engine speed [20],

- calculation of parameters such as: power, torque, specific fuel consumption and hydrocarbons emission determined on the basis of input parameters: the intake valves timing and engine speed [19],

- impact analysis of engine speed and valve timing on fuel consumption and torque [9],

- prediction of fuel consumption and exhaust gas temperature as a function of injection time [14].

The use of ANN with proper architecture and parameters (including number of layers, inputs and outputs, transfer functions, initial values of weights, learning rate and the structure of training set) - allows for complex data analysis. General characteristic of fuel consumption in dynamic states, determined on the basis of measurement data obtained from tests on engine dynamometer, allows better understanding of the engine properties. Additionally, it enables precalculations of the mileage fuel consumption for a car with a given engine in any virtual driving cycle. It also provides the possibility to perform the simulations at the design stage of the vehicle and the proper choice of its parameters in terms of the optimal combination of tractive properties and fuel economy. Hereinafter the term momentary fuel consumption is equivalent to average fuel mass flow $\overline{\mathrm{G}}$ in the time interval $\Delta \mathrm{t}=0.1 \mathrm{~s}$.

\section{Research scope and methodology}

The tests were carried out on a SI internal combustion engine of a displacement of $0.899 \mathrm{dm}^{3}$. In order to do research in dynamic states it is essential to use engine brake which enables smooth and rapid load changes. In this case hydraulically controlled friction brake was used (Fig. 1). The researcher controls two parameters: the brake load and throttle opening angle (in range $0-90^{\circ}$ ), so all the engine working cases described by relations (1) - (5) can be realized.

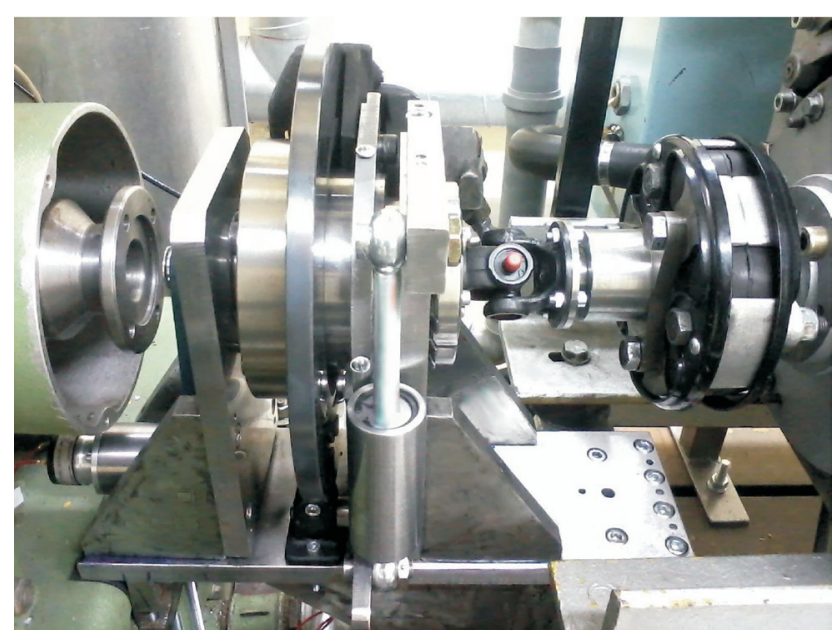

Fig. 1. Engine brake used for tests in dynamic states

Rys. 1. Hamulec wykorzystany do badań w stanach dynamicznych zdeterminowany jest przez cel, jaki ma zostać osiągnięty oraz czynniki, które wg badaczy mają wpływ na wynik i które mogą być zmierzone podczas badań. Wybranymi zastosowaniami SSN w dziedzinie silników spalinowych są:

- wyznaczanie jednostkowego zużycia paliwa, temperatury spalin i współczynnika nadmiaru powietrza na podstawie mocy silnika, ciśnienia efektywnego i temperatury silnika [4],

- określanie charakterystyki mocy silnika ZI oparte na pomiarach prędkości obrotowej i podciśnienia w kolektorze dolotowym wykonywane w rzeczywistych warunkach ruchu [12],

- analiza emisji cząstek stałych w silnikach ZS [2],

- wyznaczanie momentu obrotowego i jednostkowego zużycia paliwa na podstawie kąta wyprzedzenia zapłonu, kąta otwarcia przepustnicy i prędkości obrotowej [20],

- obliczanie parametrów, takich jak: moc, moment obrotowy, jednostkowe zużycie paliwa i emisja węglowodorów określanych na podstawie parametrów wejściowych: fazy otwarcia zaworów dolotowych i prędkość obrotowa silnika [19],

- analiza wpływu prędkości obrotowej i faz rozrządu na zużycie paliwa i generowany moment obrotowy [9],

- przewidywanie zużycia paliwa i temperatury spalin na podstawie różnych czasów wtrysku [14].

Zastosowanie odpowiedniej struktury i parametrów SSN, do których zalicza się: liczbę warstw, wejść i wyjść, funkcje przeniesienia, początkowe wartości wag, współczynnik uczenia, budowa zbioru uczącego danych, pozwalają na przeprowadzenie złożonej analizy danych. Ogólna charakterystyka zużycia paliwa w dynamicznych stanach pracy, sporządzana na podstawie wyników badań przeprowadzanych na hamowni silnikowej, pozwala lepiej poznać właściwości silnika. Ponadto umożliwia wstępne obliczanie przebiegowego zużycia paliwa pojazdu wyposażonego w dany silnik, w dowolnie konfigurowanych wirtualnych cyklach jezdnych. Daje to możliwość przeprowadzania symulacji w szerokim zakresie już na wstępnym etapie projektowania pojazdu, a przez to odpowiedniego doboru jego parametrów konstrukcyjnych w aspekcie optymalnego połączenia właściwości trakcyjnych i ekonomicznej eksploatacji. W dalszej części artykułu termin chwilowe zużycie paliwa jest równoznaczny ze średnim masowym strumieniem paliwa $\overline{\mathrm{G}} \mathrm{w}$ przedziale czasu $\Delta \mathrm{t}=0,1 \mathrm{~s}$.

\section{Przedmiot i metodyka badań}

Badania przeprowadzono na silniku spalinowym ZI o objętości skokowej $899 \mathrm{~cm}^{3}$ marki Fiat. W celu przeprowadzenia badań w stanach dynamicznych konieczne jest zastosowanie hamulca umożliwiającego płynną i szybką zmianę obciążenia silnika. W badaniach użyto hamulca ciernego (rys. 1) spełniającego powyższe wymagania regulacyjne. Operator steruje w trakcie badań: obciążeniem hamulca i kątem otwarcia przepustnicy (w zakresie $0-90^{\circ}$ ), dzięki czemu mogą być zrealizowane wszystkie przypadki pracy silnika opisane zależnościami (1) - (5). 
During the tests three engine operating parameters were measured: engine speed, resistance torque and fuel mass flow. Measurements were done for the nominal engine temperature of about $90^{\circ} \mathrm{C}$.

An example graph of engine parameters in dynamic measurement as on the left but in the coordinate system torque - engine speed (no visible information about fuel mass flow $\mathrm{G})$.
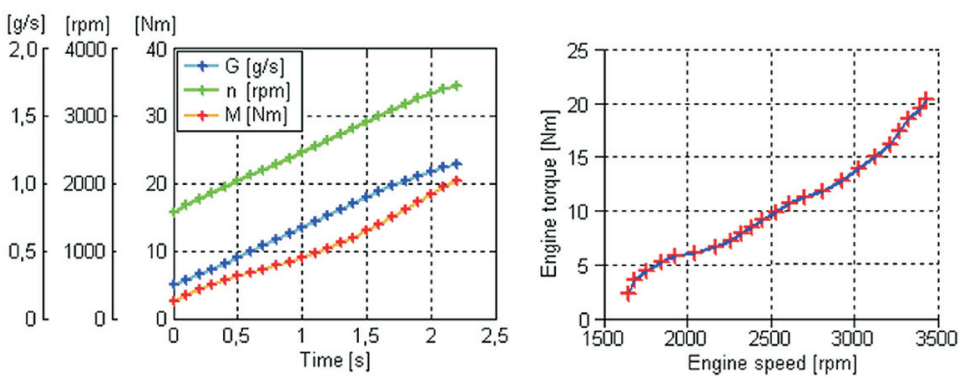

Fig. 2. Engine working parameters for a single measurement in dynamic states Rys. 2. Parametry pracy silnika dla jednego pomiaru $w$ stanach dynamicznych states is shown in Fig. 2. The right side shows the same

Podczas badań mierzone były trzy parametry pracy silnika: prędkość obrotowa, moment oporu i masowy strumień paliwa. Pomiarów dokonywano dla nominalnej temperatury pracy silnika, tj. około $90{ }^{\circ} \mathrm{C}$.

Przykładowy wykres parametrów pracy silnika w stanach dynamicznych przedstawiono na rys. 2 . Z prawej strony widoczny jest ten sam pomiar co z lewej, jednakże w układzie współrzędnych moment obrotowy-prędkość obrotowa (bez widocznej informacji o masowym strumieniu paliwa $G$ ).

$\mathrm{Na}$ rysunku 3 przedstawiono elementarne przejście między dwoma następującymi po sobie stanami pracy. W dalszej części artykułu pochodne będą zastąpione w opisie skończonymi przyrostami $\Delta$ (wynika to z zastosowania metody w obliczeniach numerycznych).

W celu sporządzenia ogólnej charakterystyki należy przeprowadzić pomiary obejmujące przypadki opisane zależnościami (1) - (5).

Istotne jest, aby w trakcie pomiarów uwzględnione były stany przechodzenia od zmiennej do stałej prędkości obrotowej i odwrotnie. Na rysunku 4 zaprezentowano przebiegi parametrów, jakie należy zrealizować w badaniach, aby zapewnić

Figure 3 shows an elementary transition between two successive states. Hereinafter the derivatives will be replaced by finite increments $\Delta$ (it is due to the fact that the method is applied in numerical calculations).

In order to determine the general dynamic characteristic, measurements should be carried out for cases described in relations $(1)-(5)$.

$$
\begin{aligned}
& \text { 1. } \frac{\mathrm{dn}}{\mathrm{dt}}>0 ; \frac{\mathrm{dM}}{\mathrm{dt}}>0 \\
& \text { 2. } \frac{\mathrm{dn}}{\mathrm{dt}}>0 ; \frac{\mathrm{dM}}{\mathrm{dt}}<0 \\
& \text { 3. } \frac{\mathrm{dn}}{\mathrm{dt}}<0 ; \frac{\mathrm{dM}}{\mathrm{dt}}<0 \\
& \text { 4. } \frac{\mathrm{dn}}{\mathrm{dt}}<0 ; \frac{\mathrm{dM}}{\mathrm{dt}}>0 \\
& \text { 5. } \frac{\mathrm{dn}}{\mathrm{dt}}=0 ; \frac{\mathrm{dM}}{\mathrm{dt}}=0
\end{aligned}
$$

It is important to make the measurements that include transitions from states of the variable speed to a constant speed and vice versa. Figure 4 shows courses of parameters that should be realized in tests to ensure effective learning of ANN. Marked dots suggest points to go to a static state and then continue the measurement along the line.

The courses described in Fig. 4 by lines inclined at a steep angle to the horizontal axis, where there is a large increase in torque and a small increase in engine speed, characterize the situation where the driver suddenly changes the throttle opening angle. Therefore, the measurements must be carried out in a short time $(0.5-3 \mathrm{~s})$. However, the courses described by nearly horizontal lines characterize very slow throttle opening/closing, resulting in a small change in the value of the torque and skuteczne uczenie SSN. Punktami oznaczono sugerowane miejsca, w których należy przejść do statycznego stanu pracy, a następnie kontynuować pomiar wzdłuż zadanej linii.

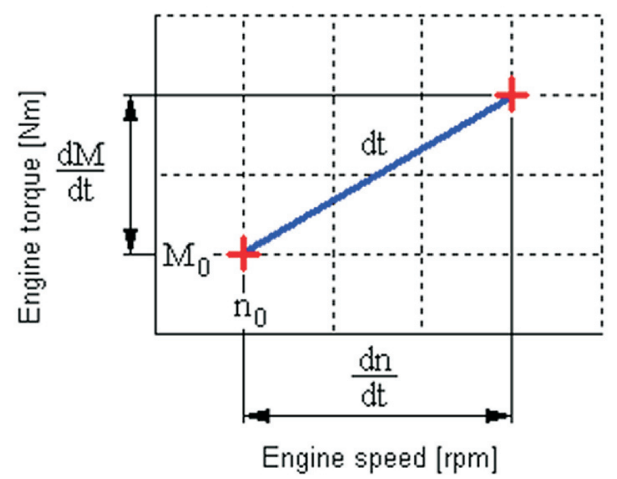

Fig. 3. Elementary transition between two successive engine work states Rys. 3. Elementarne przejście między dwoma kolejnymi stanami pracy silnika

Przebiegi opisane na rys. 4 liniami o dużym kącie nachylenia do osi poziomej, gdzie występuje duży przyrost momentu obrotowego i niewielki prędkości obrotowej, charakteryzują sytuacje, w których kierowca nagle zmienia kąt otwarcia przepustnicy. $Z$ tego powodu te pomiary należy przeprowadzać w krótkim czasie $(0,5-3 \mathrm{~s})$. Z kolei przebiegi prawie poziome charakteryzują wolne otwieranie/zamykanie przepustnicy, czego skutkiem jest niewielka zmiana wartości momentu obrotowego i większa zmiana prędkości obrotowej, dlatego pomiary te należy przeprowadzać w dłuższym czasie (10-30 s). Dla sytuacji pośrednich, gdy kąt nachylenia linii wynosi ok. $30-60^{\circ}$, należy zastosować pośrednie długości czasu pomiaru. Sugerowane czasy dotyczą tylko pomiarów opisanych liniami ciągłymi. Dla linii z punktami jest on dłuższy o czas pracy w stałych stanach. 

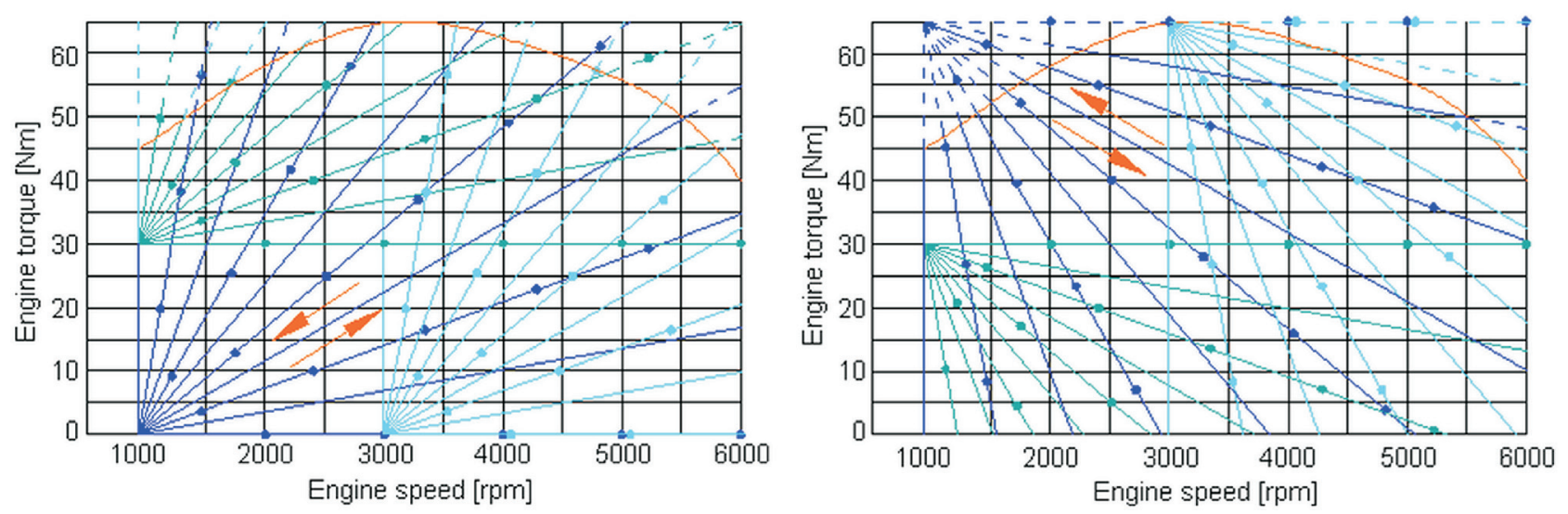

Fig. 4. Schematic representation of carrying out measurements in dynamic states

Rys. 4. Schematyczne przedstawienie przeprowadzania pomiarów $w$ stanach dynamicznych

greater change in the engine speed. Therefore, these measurements should be carried out over a long time (10-30 s). For the intermediate cases, when the angle of the line is approximately $30-60^{\circ}$, medium lengths of measurement time should be used. Suggested times refer only to measurements described by solid lines. In case of lines with the marked dots, measurement time is extended by working time in static states.

The delay in crankshaft assembly response to the control signal, which is increase in the mass fuel flow, has a significant influence on the momentary fuel consumption (Fig. 5). The increase in mass fuel flow beginning at the time $t_{1}$ does not influence neither the engine speed nor the torque in the time interval $t_{1} \rightarrow t_{2}$. This is a delay time resulting from the specificity of the phenomena occurring in the engine. Although the engine speed and torque in the time interval $\mathrm{t}_{1} \rightarrow \mathrm{t}_{2}$ are the same as in the previous one $\mathrm{t}_{0} \rightarrow \mathrm{t}_{1}$, the value of average fuel mass flow $\overline{\mathrm{G}}\left(\mathrm{t}_{1} \rightarrow \mathrm{t}_{2}\right)$ is greater than $\overline{\mathrm{G}}\left(\mathrm{t}_{0} \rightarrow \mathrm{t}_{1}\right)$. This is a proof that in the dynamic states the analysis can not only be limited to the parameters in the time interval $\Delta \mathrm{t}$, for which the average fuel mass flow is to be calculated, but also the values of engine speed and torque in the moments following the analyzed time interval should be considered.

Average fuel mass flow $\overline{\mathrm{G}}$ in the time interval $\Delta \mathrm{t}=\left(\mathrm{t}_{0} \rightarrow \mathrm{t}_{1}\right)$ can be written as a non-linear function of the following variables:

$$
\begin{aligned}
\left.\mathrm{t}_{0} \rightarrow \mathrm{t}_{1}\right) & =\mathrm{f}\left[\mathrm{n}\left(\mathrm{t}_{0}\right), \Delta \mathrm{n}\left(\mathrm{t}_{0} \rightarrow \mathrm{t}_{1}\right), \Delta \mathrm{n}\left(\mathrm{t}_{1} \rightarrow \mathrm{t}_{2}\right),\right. \\
& \left.=\mathrm{M}\left(\mathrm{t}_{0}\right), \Delta \mathrm{M}\left(\mathrm{t}_{0} \rightarrow \mathrm{t}_{1}\right), \Delta \mathrm{M}\left(\mathrm{t}_{1} \rightarrow \mathrm{t}_{2}\right)\right]
\end{aligned}
$$

where: $\mathrm{n}\left(\mathrm{t}_{0}\right)$ - initial value of engine speed, $\Delta \mathrm{n}\left(\mathrm{t}_{0} \rightarrow \mathrm{t}_{1}\right)-$ change in engine speed in the analyzed period of time $\Delta t$, $\Delta \mathrm{n}\left(\mathrm{t}_{1} \rightarrow \mathrm{t}_{2}\right)-$ change in engine speed after the analyzed period of time $\Delta \mathrm{t}, \mathrm{M}\left(\mathrm{t}_{0}\right)$ - initial value of the torque, $\Delta \mathrm{M}\left(\mathrm{t}_{0}\right.$ $\rightarrow \mathrm{t}_{1}$ ) - change in engine torque in analyzed period of time $\Delta \mathrm{t}, \Delta \mathrm{M}\left(\mathrm{t}_{1} \rightarrow \mathrm{t}_{2}\right)-$ change in engine torque after analyzed period of time $\Delta t$.

Determining a non-liner relation (6) requires the analysis of six variables. Therefore ANN was used to develop fuel consumption dynamic characteristic.
Istotny wpływ na chwilowe zużycie paliwa odgrywa opóźnienie reakcji układu korbowo-tłokowego na zwiększenie strumienia paliwa (rys. 5). Rozpoczęcie zwiększania strumienia paliwa $\mathrm{G} w$ chwili $\mathrm{t}_{1}$ nie wpływa $\mathrm{w}$ przedziale czasu $\mathrm{t}_{1} \rightarrow \mathrm{t}_{2}$ ani na prędkość obrotową, ani na moment obrotowy. Jest to czas zwłoki układu wynikający ze specyfiki zjawisk zachodzących w silniku. Mimo że prędkość obrotowa i moment obrotowy w przedziale czasu $\mathrm{t}_{1} \rightarrow \mathrm{t}_{2}$ są takie same jak we wcześniejszym przedziale $\mathrm{t}_{0} \rightarrow \mathrm{t}_{1}$, to średnia wartość strumienia paliwa $\overline{\mathrm{G}}\left(\mathrm{t}_{1} \rightarrow \mathrm{t}_{2}\right)$ jest większa niż $\overline{\mathrm{G}}\left(\mathrm{t}_{0} \rightarrow \mathrm{t}_{1}\right)$. Jest to dowód na to, że w stanach dynamicznych analiza nie może być ograniczona tylko do parametrów pracy w przedziale czasu $\Delta \mathrm{t}$, dla którego ma być obliczony średni masowy strumień paliwa, ale należy uwzględnić wartości prędkości obrotowej i momentu obrotowego w chwilach czasu $\mathrm{t}_{1} \rightarrow \mathrm{t}_{2}$ następujących po analizowanym przedziale czasu $\mathrm{t}_{0} \rightarrow \mathrm{t}_{1}$.

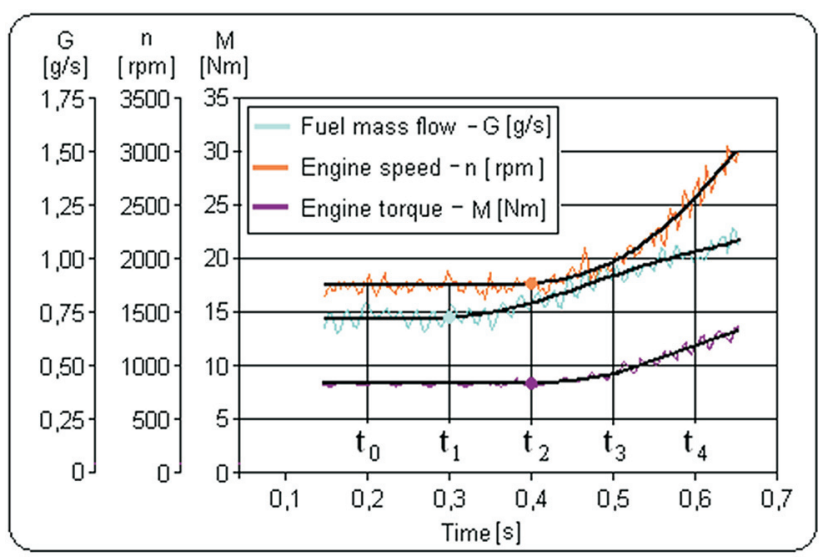

Fig. 5. Graph of engine working parameters measured during tests in dynamic states

Rys. 5. Wykres parametrów pracy silnika zmierzonych $w$ trakcie badań $w$ stanach dynamicznych

Średni masowy strumień paliwa $\overline{\mathrm{G}}$ w przedziale czasu $\Delta \mathrm{t}=\left(\mathrm{t}_{0} \rightarrow \mathrm{t}_{1}\right)$ można zapisać jako nieliniową funkcję zmiennych (6), gdzie: $\mathrm{n}\left(\mathrm{t}_{0}\right)$ - początkowa wartość prędkości

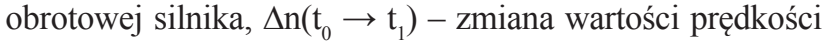
obrotowej w analizowanym przedziale czasu $\Delta \mathrm{t}, \Delta \mathrm{n}\left(\mathrm{t}_{1} \rightarrow \mathrm{t}_{2}\right)$ - zmiana wartości prędkości obrotowej po analizowanym przedziale czasu $\Delta \mathrm{t}, \mathrm{M}\left(\mathrm{t}_{0}\right)$ - początkowa wartość momentu 


\section{Analysis of test results with the use of ANN}

There are many types of ANN and learning modes but the final choice is constrained by the problem to be solved. To calculate momentary fuel consumption in dynamic states a static, two-layer, feedforward, non-linear ANN trained with gradient method in supervised mode was used. Additionally, variable learning rate and momentum factor were implemented. The calculations were carried out in Matlab [3] with use of algorithms from the literature $[10,11,13,18]$.

The task of ANN is to calculate the correct values of the momentary fuel consumption for any input vectors (engine speed and torque). This is possible only when the weights have proper values. They are adjusted during learning (training) process. In the following training steps the inputs (measured values of $n$ and $M$ ) are presented to the network, while calculated output is compared to the target (measured value of $\mathrm{G}$ ). In this way, the network error is determined. The values of all weights are adjusted in proportion to its value in every training step. The training process continues until the mean square error for the entire training set reaches a minimum value.

In a given example the ANN was trained with a set of nearly 10000 pieces of data obtained from 300 measurements in dynamic states. Randomly chosen measurements are shown in Fig. 6.

For a large number of measurements the whole field of engine work fills evenly so that the ANN learning is very

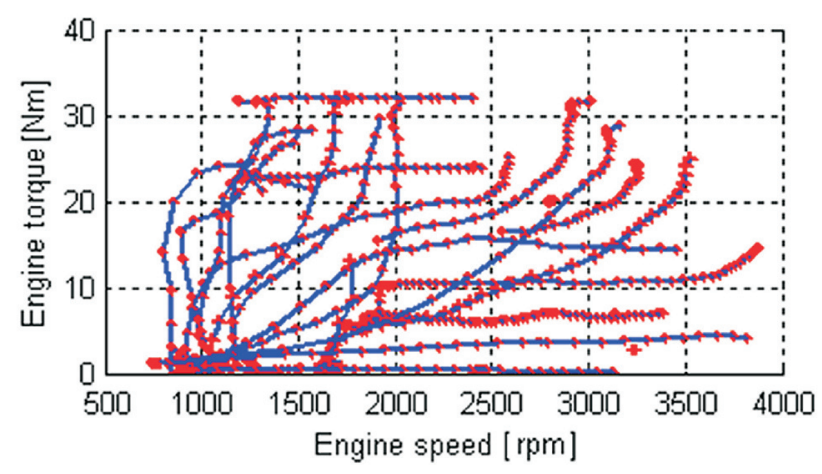

Fig. 6. Randomly chosen measurements in dynamic states Rys. 6. Losowo wybrane pomiary w stanach dynamicznych

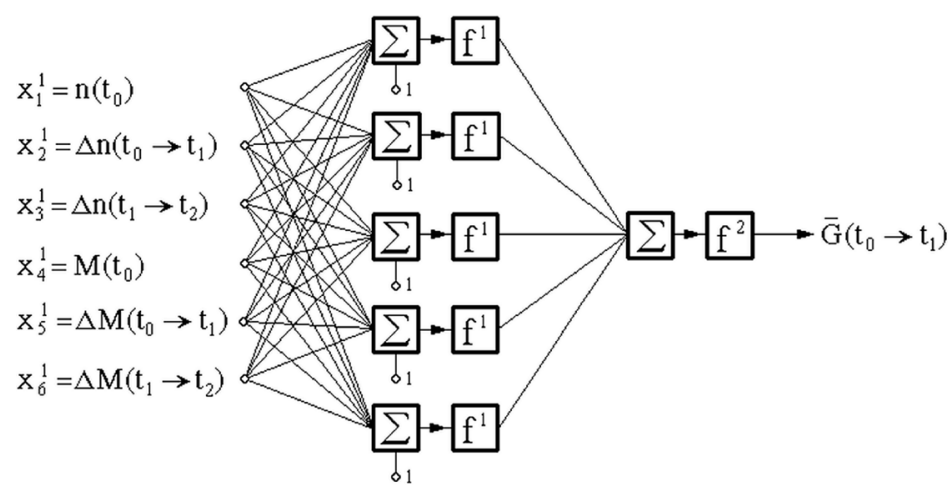

Fig. 7. Artificial neural network used for computing momentary fuel consumption in dynamic states of the engine

Rys. 7. Sztuczna sieć neuronowa użyta do obliczania chwilowego zużycia paliwa w stanach dynamicznych pracy silnika obrotowego silnika, $\Delta \mathrm{M}\left(\mathrm{t}_{0} \rightarrow \mathrm{t}_{1}\right)$ - zmiana wartości momentu obrotowego w analizowanym przedziale czasu $\Delta \mathrm{t}, \Delta \mathrm{M}\left(\mathrm{t}_{1} \rightarrow \mathrm{t}_{2}\right)$ - zmiana wartości momentu obrotowego po analizowanym przedziale czasu $\Delta \mathrm{t}$.

Wyznaczenie nieliniowej zależności (6) wymaga analizy sześciu zmiennych. Z tego powodu wykorzystano SSN do opracowania charakterystyki dynamicznej zużycia paliwa.

\section{Analiza wyników badań z zastosowaniem SSN}

Istnieje wiele rodzajów sztucznych sieci neuronowych i sposobów ich uczenia, ale ostateczny jej wybór zdeterminowany jest przez problem, który ma być rozwiązany. Do obliczania chwilowego zużycia paliwa w dynamicznych stanach pracy wykorzystano statyczną, dwuwarstwową, jednokierunkową, nieliniową SSN uczoną w sposób nadzorowany metodą gradientową. Dodatkowo zastosowano zmienny współczynnik uczenia i współczynnik momentum. Obliczenia przeprowadzono w programie Matlab [3], $\mathrm{z}$ wykorzystaniem algorytmów zawartych w literaturze [10, $11,13,18]$.

Zadaniem SSN jest obliczanie poprawnych wartości chwilowego zużycia paliwa dla dowolnych wektorów wejściowych (wartości prędkości obrotowej i momentu obrotowego). Jest to możliwe tylko wtedy, gdy wagi mają odpowiednie wartości liczbowe. Są one definiowane w trakcie procesu uczenia (trenowania). W kolejnych krokach uczenia na wejścia podawane są zmierzone wartości n i M, a obliczona odpowiedź jest porównywana z poprawną odpowiedzią (zmierzona wartość G). W ten sposób wyznaczany jest błąd sieci. Proporcjonalnie do jego wartości korygowane są wszystkie wagi w każdym kroku uczenia. Proces trenowania trwa do chwili, aż błąd średniokwadratowy dla całego zbioru uczącego osiągnie wartość minimalną.

W opisywanym przykładzie SSN uczono zbiorem blisko 10000 danych pochodzących z 300 pomiarów w stanach dynamicznych i statycznych. Losowo wybrane pomiary pokazano na rys. 6 .

Dla dużej liczby pomiarów obszar pracy silnika równomiernie wypełnia się punktami pomiarowymi, dzięki czemu uczenie SSN jest skuteczne. Na rysunku 7 przestawiono budowę SSN wykorzystanej do obliczania chwilowego zużycia paliwa.

O poprawnym funkcjonowaniu SSN decyduja wagi, które w połączeniu z zastosowanymi funkcjami przeniesienia przeliczają wartości wejściowe na wyjściowe. Poszczególne składowe SSN są następujące: macierz wejścia (7), macierz wag warstwy pierwszej (8), macierz wag warstwy drugiej (9), macierz biasów warstwy pierwszej (10), wyjście sieci (11), gdzie: $f^{1}$ - sigmoidalna funkcja przeniesienia warstwy pierwszej, $\mathrm{f}^{2}$ - liniowa funkcja przeniesienia warstwy drugiej.

SSN uczono algorytmem wstecznej propagacji błędów [10, 11, 13]. Zastosowano zmienny współczynnik uczenia i momentum, które przyspieszają proces uczenia i umożliwiają osiągnięcie najmniejszej globalnej wartości błędu. Zastosowano K = $=5$ neuronów w warstwie ukrytej. Przeprowadzona 
effective. Fig. 7 shows the structure of ANN used to calculate momentary fuel consumption.

The proper functioning of the ANN is ensured by weights which - in combination with applied transfer functions convert the input values to output values. The individual ANN components are shown below.

Input matrix:

$$
\mathbf{X}=\left[\mathrm{x}_{1}^{1}, \mathrm{x}_{2}^{1}, \mathrm{x}_{3}^{1}, \mathrm{x}_{4}^{1}, \mathrm{x}_{5}^{1}, \mathrm{x}_{6}^{1}\right]^{\mathrm{T}}
$$

$1^{\text {st }}$ layer weight matrix:

$$
\mathbf{W}^{1}=\left[\begin{array}{cccc}
\mathbf{w}_{1,1}^{1}, & \mathbf{w}_{1,2}^{1} & \ldots & \mathbf{w}_{1, \mathrm{~N}}^{1} \\
\mathbf{w}_{2,1}^{1}, & \mathbf{w}_{2,2}^{1} & \ldots & \mathbf{w}_{2, \mathrm{~N}}^{1} \\
\ldots & & & \\
\mathbf{w}_{\mathrm{k}, 1}^{1}, & \mathbf{w}_{\mathrm{k}, 2}^{1} & \ldots & \mathbf{w}_{\mathrm{k}, \mathrm{N}}^{1} \\
\ldots & & & \\
\mathbf{w}_{\mathrm{K}, 1}^{1}, & \mathbf{w}_{\mathrm{K}, 2}^{1} & \ldots & \mathbf{w}_{\mathrm{K}, \mathrm{N}}^{1}
\end{array}\right]
$$

$2^{\text {nd }}$ layer weight matrix:

$$
\mathbf{W}^{2}=\left[\mathbf{w}_{1,1}^{2}, \mathbf{w}_{1,2}^{2} \ldots \mathbf{w}_{1, \mathrm{k}}^{2} \ldots \mathbf{w}_{1, \mathrm{~K}}^{2}\right]
$$

$1^{\text {st }}$ layer bias matrix:

$$
\mathbf{B}^{1}=\left[b_{1}^{1}, b_{2}^{1} \ldots b_{k}^{1} \ldots b_{K}^{1}\right]
$$

Network output:

$$
\bar{G}=f^{2}\left[\sum_{k=1}^{K} w_{1, k}^{2} \cdot\left[f^{1}\left(\sum_{i=1}^{N} w_{k, i}^{1} \cdot x_{i}^{1}+b_{k}^{1}\right)\right]\right]
$$

$\mathrm{f}^{1}-\log$-sigmoig transfer function in first layer, $\mathrm{f}^{2}-$ linear transfer function in second layer.

ANN was trained with backpropagation algorithm [10, $11,13]$. Variable learning rate and momentum constant were implemented to accelerate training process and make learning more likely to finish in global minimum. Number of hidden neurons was set to $\mathrm{K}=5$. The analysis of the error $\mathrm{Q}$ as a function of hidden neurons number has shown that for $\mathrm{N}=5$ the smallest error $\mathrm{Q}$ is obtained with interest of the shortest learning time. The number of data in the training set was nearly 10000 therefore there was no problem of overfitting. This results from the fact that the number of data is more than twice the number of variables (weights and biases) in neural network (in this case $10000>>$ 40). Moreover, during the whole training process the validation set error was smaller than the training set error which confirms correctness of the learning process (Fig. 8 ). The analysis concerning weights initialization and adaptive learning rate during training process were carried out. It allows to avoid stopping the learning process in a shallow local minimum. With this repeatability of achieved mean square error was very high, regardless of on initial weights values. In conduced trials $\mathrm{Q}=0.0481$ \pm 0.002 . To simulate the mileage fuel consumption in point 4 , the network with the smallest Q error was used. analiza błędu Q w zależności od liczby neuronów ukrytych dowiodła, że dla $\mathrm{N}=5$ osiąga się możliwie najmniejszy błąd Q przy spełnieniu warunku najkrótszego czasu uczenia. Dla liczby danych w zbiorze uczącym równej prawie 10000 nie zachodzi problem przeuczenia się SSN. Wynika to z faktu, że liczba danych uczących jest większa od dwukrotności liczby zmiennych (wag i biasów) w sieci neuronowej (w opisywanym przypadku $10000>>40$ ). Ponadto podczas całego procesu uczenia błąd dla zbioru walidacyjnego był mniejszy niż dla zbioru uczącego, co potwierdza poprawność procesu trenowania (rys. 8). Przeprowadzono analizy dotyczące: zadawania początkowej wartości wag oraz zapewnienia właściwego przebiegu współczynnika uczenia podczas trenowania SSN. Pozwala to uniknąć zakończenia uczenia w minimum lokalnym. Tym samym powtarzalność osiąganego błędu średniokwadratowego była bardzo wysoka, niezależnie od początkowych wartości wag. W przeprowadzonych próbach uczenia SSN wynosił on $\mathrm{Q}=0,0481 \pm 0,002$. Do symulacji przebiegowego zużycia paliwa w pkt. 4 wykorzystano sieć, dla której wartość błędu Q była najmniejsza.

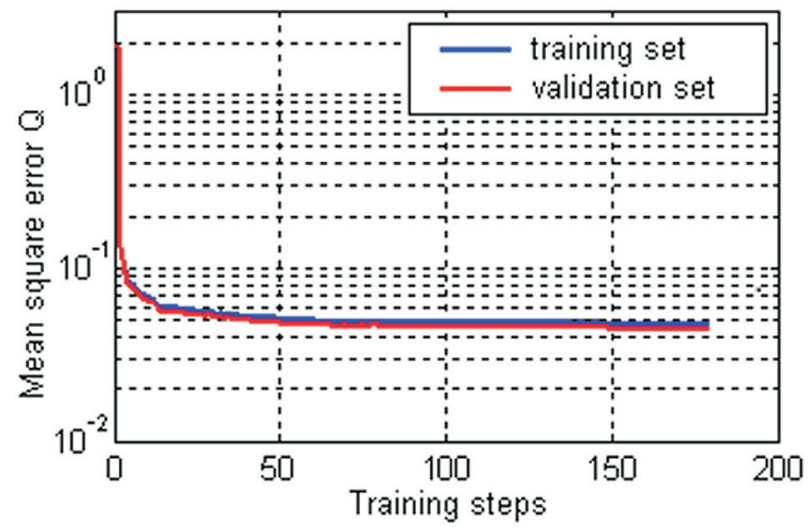

Fig. 8. Mean square error vs training epochs

Rys. 8. Wykres błędu średniokwadratowego w kolejnych krokach uczenia

Osiągnięcie minimalnej wartości błędu średniokwadratowego jest jednoznaczne z zakończeniem procesu uczenia SSN. Zdefiniowane w wyniku trenowania macierze wag po pierwsze „zawierają" dane ze zbioru uczącego (dane pomiarowe), a po drugie aproksymują je. Oznacza to, że SSN znajduje rozwiązania pośrednie, czyli takie, które nie były fizycznie zmierzone podczas badań, a które mogą występować w czasie pracy silnika w określonych warunkach użytkowania (rys. 9).

Sieć neuronowa $\mathrm{z}$ wagami i biasami $\mathbf{W}^{1}, \mathbf{W}^{2}, \mathbf{B}^{1}$, które po uczeniu sieci mają wartości stałe, staje się charakterystyką dynamiczną zużycia paliwa i może obliczać jego wartości dla dowolnych wektorów wejściowych $\mathbf{X}$ (symulacja SSN).

Dzieląc dowolny przebieg parametrów pracy silnika ( $n, M)$ na elementarne przedziały czasu $\Delta t$, można w efekcie obliczyć sumaryczną wartość zużycia paliwa w całym teście. 
Achieving a minimum value of mean square error means completion of the ANN training. The weight matrices, defined in training process, firstly 'contain' data from the training set (data obtained during measurements) and secondly approximate them. It means that the ANN can find intermediate solutions, that is, those which were not physically measured during tests but which may occur during engine operation under certain conditions (Fig. 9).

ANN with weights and biases $\mathbf{W}^{1}, \mathbf{W}^{\mathbf{2}}, \mathbf{B}^{\mathbf{1}}$, which after learning process have fixed values, becomes the fuel consumption dynamic characteristic and is capable of calculating output values of $\mathrm{G}$ for any input vectors $\mathbf{X}$ (ANN simulation).

Dividing any course of engine parameters (n, M) into elementary time intervals $\Delta \mathrm{t}$ the fuel consumption can be calculated for the entire test.

\section{Verification and concept application of the dynamic characteristic of fuel consumption}

The calculations of momentary fuel consumption are sometimes done with the use of universal characteristic [17]. The accuracy of this method for small changes in engine speed and load is sufficient, however, for rapid accelerations it leads to an error of several percent. The Fig. 10 shows the course of the engine speed, torque and momentary fuel consumption calculated in two ways: with use of universal characteristic (as a series of static states) and with dynamic characteristic determined with use of the ANN. The difference in the courses of these two graphs clearly shows that the momentary fuel consumption calculated with use of the characteristic designated with ANN (blue line) is higher. It means that the ANN method gives correct (in line with the expectations) results and proves the validity of such a characteristic, which takes into account the specificity of the phenomena occurring in the combustion engine.

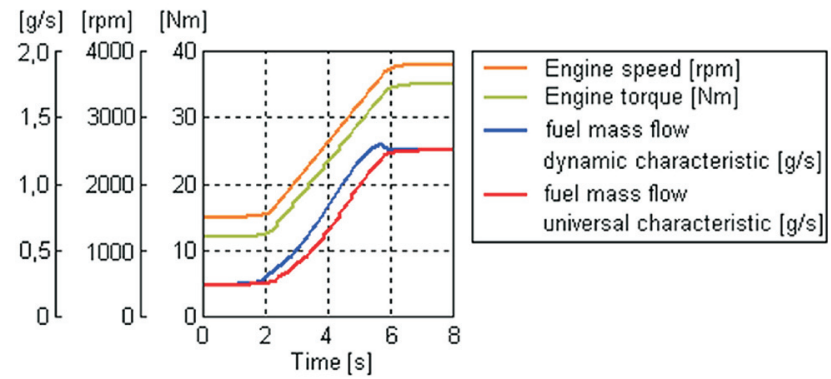

Fig. 10. Courses of fuel consumption calculated with fuel consumption dynamic characteristic designated with ANN and universal characteristic Rys. 10. Przebiegi wartości zużycia paliwa obliczanego za pomoca charakterystyki dynamicznej zużycia paliwa wyznaczonej z wykorzystaniem SSN i charakterystyki uniwersalnej

Determined dynamic characteristic can be used in simulations at design stage of the vehicle. It permits to analyze the impact of the following design factors:

- vehicle weight,

- gears and differential ratios,

- drag and rolling coefficients,

- dynamic wheel radius,

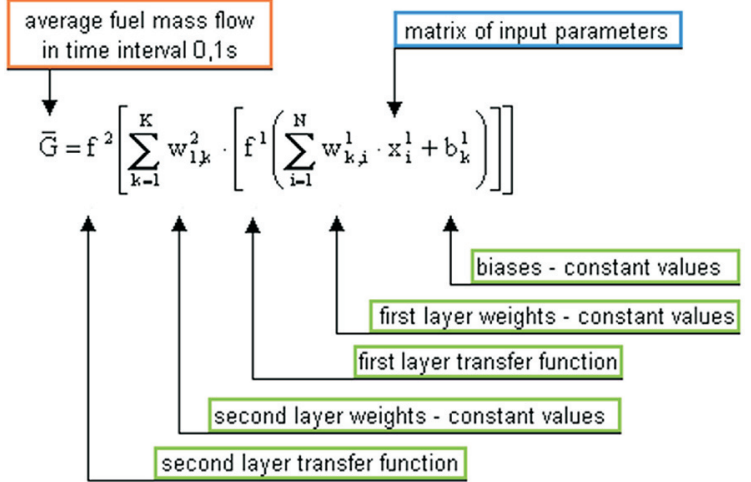

Fig. 9. Formula for computing momentary fuel consumption in dynamic states (for a given engine) - fuel consumption dynamic characteristic

Rys. 9. Wzór na obliczanie chwilowego zużycia paliwa $w$ dynamicznych stanach pracy (dla przebadanego silnika) - charakterystyka dynamiczna zużycia paliwa

\section{Weryfikacja i koncepcja zastosowania charakterystyki dynamicznej zużycia paliwa}

W obliczeniach chwilowego zużycia paliwa wykorzystuje się czasami charakterystykę uniwersalną [17]. O ile dokładność takiej metody dla małych zmian prędkości obrotowej i obciążenia jest wystarczająca, to jednak dla dużych wartości przyspieszeń prowadzi do wyników z błędem rzędu kilku procent. Na rysunku 10 przedstawiono przebieg prędkości obrotowej, momentu obrotowego silnika i wyznaczanego dla nich chwilowego zużycia paliwa wyznaczanego dwoma sposobami: charakterystyką uniwersalną (jako szereg stanów statycznych) [1] i charakterystyką dynamiczną wyznaczoną z wykorzystaniem SSN. Różnica w przebiegu obydwu wykresów jednoznacznie wskazuje, że chwilowe zużycie paliwa liczone charakterystyką wyznaczoną z wykorzystaniem SSN (linia niebieska) jest większe. Oznacza to, że metoda SSN daje poprawne (zgodne z przewidywaniami) wyniki i udowadnia zasadność sporządzania takiej charakterystyki, uwzględniającej specyfikę zjawisk zachodzących w silniku spalinowym.

Wyznaczona charakterystyka dynamiczna może być wykorzystana do symulacji na etapie projektowania pojazdu. Pozwala ona przeprowadzać analizę wpływu następujących czynników konstrukcyjnych:

- masa pojazdu,

- przełożenia w skrzyni biegów i przekładni głównej,

- współczynnik oporu powietrza i toczenia,

- promień dynamiczny koła,

- sprawność układu przeniesienia napędu

na przebiegowe zużycie paliwa w dowolnie zdefiniowanych cyklach jezdnych nieuwzględniających fazy nagrzewania silnika (badania przeprowadzano po osiągnięciu przez silnik temperatury roboczej).

Wzory (12) - (13) przedstawiają zależność między prędkością i przyspieszeniem pojazdu a parametrami pracy silnika [8]. Wykorzystując równania (12) i (13), można obliczyć moment obrotowy i prędkość obrotową silnika dla każdej chwili trwania dowolnego wirtualnego testu jezdnego. Następnie takie dane są wykorzystane do symulacji SSN. 
- and the efficiency of the transmission system, on the mileage fuel consumption in any virtual driving cycle that does not include the engine warm-up phase (tests were carried out after the engine has reached nominal operating temperature).

Formulas (12) - (13) represent relations between speed and acceleration of the vehicle and engine parameters [8]:

$$
\begin{gathered}
n(t)=\frac{v(t) \cdot 60 \cdot i_{b} \cdot i_{g}}{2 \cdot \pi \cdot r_{d}} \\
M(t)=\frac{\left(m_{p} \cdot a(t) \cdot \delta+F_{p}(t)+F_{t}\right) \cdot r_{d}}{i_{b} \cdot i_{g} \cdot \eta_{c}}
\end{gathered}
$$

The use of above equation enables calculating engine speed and torque for every moment of the virtual test. Then these data are used to simulate ANN.

Figure 11 shows the EUDC cycle [7] and the engine parameters of the car Fiat Seicento [21], calculated with use of formulas (12) - (13). Simulation of ANN with engine parameters allows to calculate momentary fuel consumption in the subsequent moments. After converting it into the mileage fuel consumption, it is $4.1 \mathrm{dm}^{3} / 100 \mathrm{~km}$.

Design parameters of the car can be changed to evaluate their impact on the mileage fuel consumption in particular cycle. In EUDC cycle (for Fiat Seicento):

- vehicle weight reduction by $30 \mathrm{~kg}$ results in the decrease of fuel consumption by $1 \%$,

- reduction of the main gear ratio by $5 \%$ decreases fuel consumption by $3.9 \%$,

- rolling resistance reduction by $5 \%$ and the drag coefficient of $5 \%$ will reduce fuel consumption by $1.5 \%$.

The application of all these changes results in reducing mileage fuel consumption to $3.9 \mathrm{dm}^{3} / 100 \mathrm{~km}$.

A very large number of such simulations allows, on the very initial vehicle design stage, for optimization of its features to ensure the best possible dynamic performance and fuel economy.

\section{Conclusions}

The use of an artificial neural network to analyze measurement data from tests carried out on engine dynamometer allows to determine fuel consumption dynamic characteristic. It takes into account the specificity of the phenomena occurring in internal combustion engines, thereby allows for:

- evaluation of the engine in dynamic states,

- simulations of mileage fuel consumption in different virtual driving cycles,

- analysis of transmission and other vehicle parameters on the basis of the virtual drive tests.

Determined characteristic enables obtaining the value of fuel consumption in any virtual test cycles without testing the engine /vehicle on the engine/ chassis dynamometer for each case. This allows to reduce costs and time spent on research, which is extremely important in the current market conditions. Example described in this paper proves that for the analysis of the phenomena occurring in internal combustion engines, described by non-linear models, ANN can be used.
Na rysunku 11 przedstawiono cykl EUDC [7] i parametry pracy silnika samochodu Fiat Seicento [21] obliczone z wykorzystaniem wzorów (12) - (13). Symulacja SSN parametrami pracy silnika pozwala obliczyć chwilowe zużycie paliwa w kolejnych chwilach testu, a po przeliczeniu go na przebiegowe zużycie paliwa wynosi ono w tym przypadku $4,1 \mathrm{dm}^{3} / 100 \mathrm{~km}$.

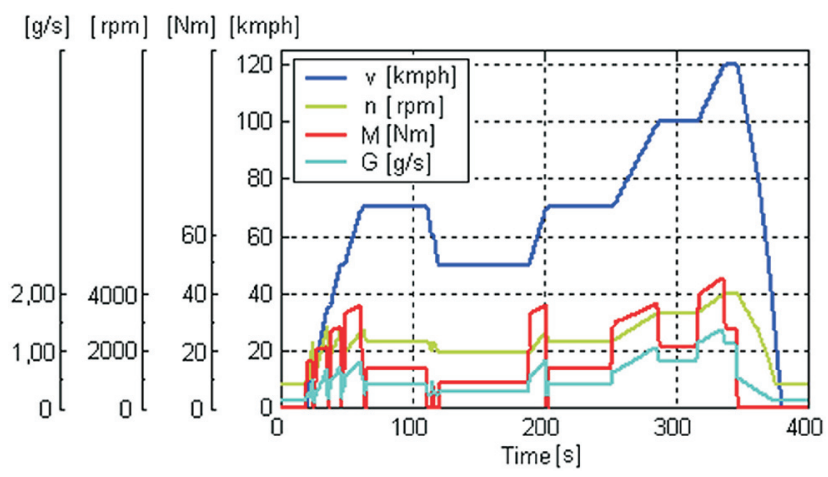

Fig. 11. Chosen engine working parameters in EUDC cycle Rys. 11. Wybrane parametry pracy silnika w cyklu jezdnym EUDC

Można dowolnie zmieniać parametry konstrukcyjne pojazdu i oceniać ich wpływ na przebiegowe zużycie paliwa w określonym cyklu. Dla cyklu EUDC (dla samochodu Fiat Seicento):

- zmniejszenie masy pojazdu o $30 \mathrm{~kg}$ skutkuje zmniejszeniem zużycia paliwa o $1 \%$,

- zmniejszenie wartości przełożenia głównego o 5 \% powoduje zmniejszenie zużycia o 3,9\%,

- zmniejszenie oporów toczenia o 5\% i współczynnika oporu powietrza również o $5 \%$ powoduje obniżenie zużycia paliwa o $1,5 \%$.

Natomiast wprowadzenie wszystkich powyższych zmian jednocześnie skutkuje zmniejszeniem przebiegowego zużycia paliwa do poziomu $3,9 \mathrm{dm}^{3} / 100 \mathrm{~km}$.

Duża liczby takich symulacji pozwala, już na wstępnym etapie konstrukcji pojazdu, optymalizować jego cechy w celu zapewnienia jak najlepszych właściwości dynamicznych i ekonomiki eksploatacji.

\section{Wnioski}

Zastosowanie metody sztucznych sieci neuronowych do analizy danych pomiarowych $\mathrm{z}$ badań przeprowadzanych na hamowni silnikowej daje możliwość sporządzenia ogólnej charakterystyki zużycia paliwa $\mathrm{w}$ dynamicznych stanach pracy. Uwzględnia ona specyfikę zjawisk zachodzących w silnikach spalinowych, dzięki czemu możliwe stają się:

- ocena pracy silnika w stanach dynamicznych,

- symulacja przebiegowego zużycia paliwa $\mathrm{w}$ dowolnych wirtualnych cyklach jezdnych,

- analiza doboru parametrów układu przeniesienia napędu i innych parametrów pojazdu na podstawie wirtualnych testów jezdnych.

Sporządzona charakterystyka umożliwia wyznaczanie wartości zużycia paliwa w dowolnych cyklach badawczych bez każdorazowego testowania silnika/pojazdu na hamowni 
At the same time it should be remembered that the accuracy of the results calculated on the basis of such characteristic strongly depends on the preliminary analysis of the data, the selection of the network initial parameters, learning process and the number of measurement data.

\section{Nomenclature/Skróty i oznaczenia:}

$\mathrm{n} \quad$ engine speed/prędkość obrotowa silnika, 1/min

$\mathrm{M}$ engine torque/moment obrotowy silnika, $\mathrm{N} \cdot \mathrm{m}$

$\mathrm{v} \quad$ vehicle speed/prędkość pojazdu, $\mathrm{m} / \mathrm{s}$

a vehicle acceleration/przyspieszenie pojazdu, $\mathrm{m} / \mathrm{s}^{2}$

$\mathrm{i}_{\mathrm{b}} \quad$ gear ratio/przełożenie skrzyni biegów

$\mathrm{i}_{\mathrm{g}} \quad$ differential ratio/przełożenie przekładni głównej

$\mathrm{r}_{\mathrm{d}} \quad$ dynamic radius/promień dynamiczny, $\mathrm{m}$

$\mathrm{m}_{\mathrm{p}}$ total weight of the vehicle/masa catkowita pojazdu, $\mathrm{kg}$

$\mathrm{d}^{\mathrm{p}}$ inertia coefficient of rotating masses/wspótczynnik bezwładności mas wirujących

$\mathrm{F}_{\mathrm{p}}$ the force of air resistance/sita oporu powietrza, $\mathrm{N}$

$\mathrm{F}_{t}^{\mathrm{p}}$ rolling resistance force/sita oporu toczenia, $\mathrm{N}$

$\eta_{\mathrm{c}}$ efficiency of the transmission/sprawność układu przeniesienia napędu

\section{Bibliography/Literatura}

[1] Bera P.: Applying neural network in computing filling coefficient of four-stroke internal combustion engine. Mechanics and Control, tom $30 \mathrm{nr}$ 2, Kraków 2011.

[2] Brzeżański M., Golomb P.: Application of neural network method to analysis of emission of particulates in CI and SI engines exhaust gas. Combustion Engines, 2009, nr 2009-SC1, s. 331-337.

[3] Brzózka J., Dorobczyński L.: Matlab. Środowisko obliczeń naukowo-technicznych. Wydawnictwo Naukowe PWN, Warszawa 2008.

[4] Çelik V., Arcaklioğlu E.: Performance maps of a diesel engine. Applied Energy. 2005, Vol. 81, Issue 3, s. 247-259.

[5] Chłopek Z.: Uwagi do badań silników spalinowych w stanach dynamicznych. Silniki Spalinowe nr 4/2010 (143).

[6] Dyrektywa Rady Wspólnot Europejskich z dnia 20 marca 1970 r. w sprawie zbliżenia ustawodawstw Państw Członkowskich odnoszących się do działań, jakie mają być podjęte w celu ograniczenia zanieczyszczania powietrza przez spaliny z silników o zapłonie iskrowym pojazdów silnikowych (70/220/EWG).

[7] Dyrektywa Rady Wspólnot Europejskich z dnia 26 czerwca 1991 r. zmieniająca dyrektywę 70/220/EWG w sprawie zbliżenia ustawodawstw Państw Członkowskich odnoszących się do działań, jakie mają być podjęte w celu ograniczenia zanieczyszczania powietrza przez emisje z pojazdów silnikowych (91/441/EWG).

[8] Gabryelewicz M.: Podwozia i nadwozia pojazdów samochodowych. 1. Podstawy teorii ruchu i eksploatacji oraz układ przeniesienia napędu. Wydawnictwa Komunikacji i Łączności, Warszawa 2010.

[9] Gölcü M., Sekmen Y., Erduranli P., Salman M. S.: Artificial neural network based modeling of variable valve timing in a spark-ignition engine. Applied Energy, 2005, Vol. 81, Issue 2, s. $187-197$.

[10] Gupta M. M., Jin L., Homma N.: Static and Dynamic Neural Networks. From Fundamentals to Advanced Theory, John Wiley \& Sons Inc, 2003. silnikowej/podwoziowej. Pozwala to ograniczać koszty i czas przeznaczany na badania, co ma niezwykle duże znaczenie w obecnych warunkach rynkowych. Przedstawiony w artykule przykład stanowi dowód, że do analizy zjawisk zachodzących w silnikach spalinowych, opisywanych nieliniowymi modelami, można z powodzeniem wykorzystywać SSN. Jednocześnie należy pamiętać, że dokładność wyników obliczanych na podstawie takiej charakterystyki silnie zależy od poprawności wstępnej analizy danych, doboru parametrów początkowych sieci, sposobu przeprowadzania procesu uczenia i liczby danych pomiarowych.

$\mathrm{G}$ fuel mass flow/masowy strumień paliwa, $\mathrm{g} / \mathrm{s}$

$\overline{\mathrm{G}}$ average fuel mass flow in the time interval $\Delta \mathrm{t}=0.1 /$ średni masowy strumień paliwa $w$ przedziale czasu $\Delta \mathrm{t}=0,1 \mathrm{~s}, \mathrm{~g} / \mathrm{s}$

$\mathrm{N}$ number of network inputs/liczba wejść do sieci $(\mathrm{N}=6)$

$\mathrm{K}$ number of neurons in hidden layer/liczba neuronów $w$ warstwie ukrytej $(\mathrm{K}=5)$

Q mean square error for the training set/bład średniokwadratowy dla zbioru uczacego

[11] Hassoun M. H.: Fundamentals of Artificial Neural Networks. The MIT Press, 1995.

[12] Mamala J., Jantos J.: Exploitation characteristics of an engine car. Journal of KONES, 2005, Vol. 12, No. 1-2, s. 217-224.

[13] MathWorks, Neural network toolbox: user's guide (Release 2010b), 2010, http://www.mathworks.com/ (20.12.2010).

[14] Parlak A., Islamoglu Y., Yasar H., Egrisogut A.: Application of artificial neural network to predict specific fuel consumption and exhaust temperature for a diesel engine. Applied Thermal Engineering 26, 2006, Vol. 26, Issues 8-9, s. 824-828.

[15] Praszkiewicz T., Sobieszczański M.: Realizacje testów badawczych na zautomatyzowanej hamowni silników spalinowych. Journal of KONES Internal, Combustion Engines 2002.

[16] Romaniszyn K.M., Wnęk H.: Aproksymowane charakterystyki dynamiczne pojazdów budowane na podstawie testów jezdnych. Silniki Spalinowe, nr 3/2011 (146).

[17] Serdecki W.: Badania silników spalinowych: laboratorium, wyd. 2. Wydawnictwo Politechniki Poznańskiej, Poznan 2001.

[18] Tadeusiewicz R.: Sieci neuronowe. Akademicka Oficyna Wydawnicza, Warszawa 1993.

[19] Taşdemir Ş. [i in.]: Artificial neural network and fuzzy export system comparison for prediction of per formance and emission parameters on a gasoline engine. Expert Systems with Applications, 2011, Vol. 38, Issue 11, s. 13912-13923.

[20] Togun N. K., Baysec S.: Prediction of torque and specific fuel consumption of a gasoline engine by using artificial neural networks. Applied Energy, 2010, Vol. 87, Issue 1, s. 349-355.

[21] Zembowicz J.: Fiat Seicento. WKŁ, Warszawa 2010.

Piotr Bera, MEng. - Assistant, Faculty of Mechanical Engineering and Robotics, AGH University of Science and Technology, Cracov.

Mgr inż. Piotr Bera - asystent na Wydziale Inżynierii Mechanicznej i Robotyki Akademii GórniczoHutniczej Katedra w Krakowie.

e-mail:pbera@agh.edu.pl 